\title{
THE ROLE OF PRE-SCHOOL EDUCATION IN THE CHILD'S DEVELOPMENT AND ANALYSIS OF CURRENT PRE-SCHOOL EDUCATION SYSTEM IN UZBEKISTAN
}

\author{
NiGORA MAMADAMINOVA
}

\begin{abstract}
The author of the article attempts to analyze the current pre-school education system of Uzbekistan, its main challenges, shortcomings and reforms. Moreover, this research will provide the study of the importance of learning at early ages (3-5) and its impact on the future learning and personal development of children. The research highlights the analysis of domestic and foreign prospects of the studied issue. Namely, the researcher presents the view that developed countries pay more and more attention to boost the quality of pre-school educational institutions, the efficiency of curriculum, and implementation of more social activities to enhance the development of children's soft skills; however, this is not the case in developing countries such as Uzbekistan. Thus, the goal of the paper would be to elaborate on the need to consider, remodel and upgrade the pre-school education system further and trigger to start some campaigns which will aim to develop young mother's personal and professional development. The study will highlight the impact of pre-school education by evaluating the literature in the field, looking deeper at the experience of developed countries as well as considering the situation in Uzbekistan regarding the mentioned area. The findings of the paper can be deployed to prepare educational policy and contribute to the development of the entire education system of Uzbekistan.
\end{abstract}

Keywords: pre-school education, early childhood education, ECE, child's development, Uzbekistan.

\section{INTRODUCTION}

The current researches on children's learning and their future performances as students at higher levels of educational institutions demonstrate the significance of pre-school education. The studies held in the US and Europe show that children who practiced some learning process before going to school perform better than others at primary, secondary schools, and even at universities. Thus, the young generation should be on focus since early ages of development by their families and government in order to ensure a bright future for them.

In history, when prominent scientists such as Al-Khwarizmi, Alfraganus, Farobiy, Beruni, Avicenna, Navoi, Bobur, Mirzo Ulugbek, and others from Central Asia contributed to the world heritage in such areas as Math, Geography, Astronomy, Medicine, Music, Linguistics, Philosophy, Ethics, History and others, it was obligatory to start learning at early ages. Therefore, our ancestors appreciated learning at early ages and the performance was outstanding. 
Nowadays the government of Uzbekistan is trying to raise the level of literacy and overall quality of education within the country. New high schools and universities, especially those which were created in co-operation with foreign countries seem to be in great demand. However, due to the fact that not enough interest, attention, and importance was made for about 25 years into the pre-school educational institutions, children on the following levels of education seem to be struggling and the academic performance of pupils is not satisfactory today. Besides, it should be highlighted that even though Uzbekistan is the most populated country in Central Asia and the second populated one in post-Soviet Union countries after Ukraine, the number of kindergartens is insufficient. Moreover, the educational program at pre-school educational institutions are quite outdated and need to be reconsidered by the government.

This article is intended to bring benefit in terms of recognizing the importance of early childhood education and understanding the value of investing in pre-school education in developing countries, particularly in Uzbekistan.

\section{THEORETICAL BACKGROUND}

The research conducted in the field of neuroscience and brain development at Harvard University showed that it is crucial to invest in the early childhood development in order to maintain prosperous society. Starting from birth to five years are the most productive for developing cognitive skills and acquiring knowledge. The stronger the emotional, physical, social skills with cognitive-linguistic ability at early ages, the more successful the child becomes later at school and even in the workplace. [1]

Until the 1980s stimulating young children's development was not very popular even in the curriculum of developed countries. Preschools in most communities served as a child caring institutions. However, for the last decades the importance of early childhood learning and socialization is becoming more actual and this phenomena has gained more interest especially in European countries, such as Finland, Sweden, Norway, UK, Belgium, Denmark, France, Netherlands and others. These countries prioritize early childhood development and keep long-term investments. [2]

Earlier studies accomplished in 1964 by Hunt, Deutsch explained that children at the first years of life have great potential to learn and it is critical for future life and career. Bloom (1964) also highlighted the periods when children are able to learn fast and effectively to be the first five years of life. Hunt's and Bloom's theoretical writings stimulated the awareness and development of pre-school education in above mentioned countries. Later Midness and Keliher (1968) evaluated 47 researchers on the importance of pre-school education and suggested to include kindergartens into the public education system of the United Kingdom. [3]

Studies accomplished by Myers (1992) described that children who were exposed to pre-school education are prepared to the environment of school better than those who were not. They showed better performance in subjects such as English language, Mathematics and science than their peers who did not have background experience. Besides, Milbank and Osborn (1987) explored that while children interact with their friends and get engaged in various activities at kindergartens, they improve their cognitive skills [4]. At this stage, children are curious, eager to learn everything around them and they acquire information promptly. According to the researches, positive atmosphere is also essential in the growth of a child both mentally and physically. [2] Therefore, attending pre-schools from early ages can be beneficial to overall health of young generation as well. Besides, pupils with earlier experience in nursery schools do not feel shy and feel much more confident while interacting with peers or teachers. They feel free to take part in different activities and enjoy the process due to the fact that they had positive experience in pre-school settings. [5]

Ms. Gopnik (2014) and her colleagues observed that youngsters at the ages of 4-5 were better than grown-ups at recognizing and analyzing the events happening around them, particularly cause and effect situations. Pre-school children were more open-minded while analyzing the evidences with improbable and uncommon associations. However, adults had difficulties compared to youngsters in 
the evaluation due to their already established ways of perception. [6] Thus, pre-school education is useful to expand children's both soft and hard skills.

On the other hand, not all children have opportunity and access to attend pre-school settings or acquire knowledge from parents at home. Brophy (2006) explained that disadvantaged children due to the fact that they have limited access to books, educational games, toys and cannot have enough experience in visiting educational places such as museums and zoos, are not well-prepared for the school activities [7]. Poverty or limited access to educational experience and materials impact child development negatively. An American charity project named "The Opportunity Project (TOP)" ran a research during the period of 2007-2012 in this area investigating the long-term benefits of its own early childhood education programs on disadvantaged children. The Program itself was founded to support children and families in poverty, provide them necessary educational tools and it applies the curriculum based on the guidelines of the National Association of the Education of Young Children (NAEYC). The findings of five-year-long research showed that when children are exposed to early education, they were still active at school at learning and social activities. Moreover, engagement of children into learning since early ages is beneficial for their brain development as well. Besides, these children were displaying more emotionally mature behavior compared to others. So for at least five years, high-quality pre-school education brings success in terms of educational achievements, social interactions and other activities together with emotional stability. [8]

Another project which explored the impacts of early education in children's future achievements is the Effective Provision of Pre-School Education (EPPE) project. It is the first European longitudinal study which focused on investigating young children's (aged 3-4) development. The project explored the short term and medium term effect of pre-school education, pre-school characteristics on children and home learning environment on children's development. The results of the research revealed that starting education at young ages plays an important role in reducing social discriminations; both the quantity and quality of pre-school education are influential; pre-school has a positive impact over family influences. Other findings explain that in order to make children more progress, staff/parent should also understand child development along with curriculum knowledge; children who attended pre-school compared to "home-school" attenders demonstrated better concentration on subjects, sociability and other soft skills when they started school; time spent at pre-school settings do not make any difference, the child who attended full-time and the child who attended part-time have no big discrepancy in the development; there is a strong association between children's performance at school and parental factors; disadvantages such as socio-economic status, low income, mother's age and level of education correlate with lower academic performance at school. [9]

The above-mentioned researches well-indicates the importance and role of early childhood education in the development of children and their future success. At the same time, acquired cognitive skills lead to a better and higher income, thus economic growth of the whole country. There is a strong correlation between cognitive skills and economic growth. [10] Unfortunately, developing countries do not pay enough attention to the role of child education and cognitive skills compared to developed countries. Further, the experiences of high-ranked countries based on the best pre-school education provision will be discussed.

\subsection{EXPERIENCE OF DEVELOPED COUNTRIES IN PRE-SCHOOL EDUCATION SYSTEM}

According to the results of Starting well, an Economist Intelligence Unit (EIU) research program [11], Nordic countries (Finland ranking on top) are taking the first four top six places on the best preschool provision. Asian countries such as South Korea (10), Japan (21), Singapore (29), Taiwan (30), Malaysia (36) and Indonesia (44) are also included in the list.

It is important to emphasize that Finland ensures quality by developing teaching as a professional career. Pre-school education teachers must have at least Bachelor's degree, while most teachers complete a Master's degree too. However, in order to work as a teacher at primary levels, it is mandatory to have a Master's degree too. Teachers are respected and paid well in Finland; a class ratio is 11 students per teacher. 
The Index used different factors to measure the ranking of countries. The first aspect was availability of pre-school entities to each family. Belgium comes first and the data indicates that $99.7 \%$ of children attend free pre-school from the age of two and a half. The next top countries in terms of availability are Norway (98.6\%), UK (97.7\%), Sweden (97.5\%), Finland (94.9\%), while the four bottom listed countries are China (34.8\%), Turkey (33.5\%), India (21.8) and Indonesia (11.5). Of course, there are different factors impacting this aspect of availability which include territory of the country, population, distance between pre-school facilities and home of children.

Affordability is the next index to measure the best pre-school education. In some countries such as China and USA the cost of pre-school education is even higher than universities or colleges. There are certain countries which provide subsidies for disadvantages families but the cost varies. On the other hand, the countries which recognized the role of ECE, are making sure that these services are affordable for the families. For instance, Ireland introduced one year free pre-school education as of 2010. Other examples can be UK and France which provide free pre-school education from the age of three to all children. However, in UK the number of allowed hours is 15 hours per week while France grants full day programs, but some services such as lunch or additional childcare hours are charged. Those chargeable services can be paid with the help of subsidies. The index of affordability not only measures how costly are the services of pre-school entities, but it also takes into account the system of subsidies and tax credits for disadvantaged families. The top countries based on this index are Norway, Denmark, Sweden and Finland.

In order to achieve goals in terms of child development, it is essential to ensure the quality of education. The factors which influence the quality are student-teacher ratio in the groups; training and improving skills of employees; developing curriculum guidelines; maintaining parents' awareness and involvement; providing good health and safety conditions; building collaborations with primary school system; establishing structured data collection system, and others. These factors were considered while measuring the index of quality. Finland, Sweden, UK, Norway are on the top, Czech Republic, Spain, USA, Greece in the middle and Vietnam, Philippines, Indonesia and India in the end of the list. New Zealand ranked as the $7^{\text {th }}$ on the list in the current index, started transformation of childhood education services 35 years ago. The government developed a mechanism where each children had opportunity to attend pre-school child care and education settings from birth till the age of five 30 hours a week. Moreover, the importance of qualified teachers was recognized and all the professionals working in pre-schools were retrained at universities. ECE services receive more funding from the government based on the number of qualified teachers in the entity.

The research program showed the improvements in the field of early childhood education and the role of investments in human capital for a better future of society. Ensuring high-quality education at the early ages which are available and affordable to the population within the country demands continuing steadfastness from the government. At the same time, the above-mentioned data can encourage policymakers of developing countries such as Uzbekistan.

\subsection{ANAlysis of A CURRENT PRE-SCHOOL EDUCATION SYSTEM IN UZBEKISTAN}

After the collapse of the Soviet Union, the countries experienced an economic downturn, political instabilities, and social conflicts. Particularly Central Asian states were negatively affected by the economic transition and consequently, the pre-school education system was influenced tremendously as the amount of funding reduced significantly. Many facilities providing early childhood education were closed down or even half destroyed by the ethnic conflicts. Due to the insufficient number of preschool settings, official and unofficial fees emerged which were not affordable to many households. Only after 2000, enrolments to Early Childhood Care and Education Programs (ECCE) started increasing [12].

According to the data from UNICEF (2013), the percentage of enrolled children aged from three to six years into ECCE in Uzbekistan during 2000-2006 increased from 19.1\% to 21.2\% while Kazakhstan elevated the percentage from $25.6 \%$ to $40.7 \%$. Another Post-Soviet Union country, Ukraine reached 
$71.3 \%$ compared to the initial enrolment level being $49.8 \%$ during the same period of time. [13] The minor change of Uzbekistan can be noticed above.

The researcher Habibov (2014) observed that there are variables that influence the families' decision about children's enrolment to ECCE. One of the key factors which is associated with enrolment in Uzbekistan is the mother's education and her awareness about the importance of pre-school education. The next element is the financial condition of the families. Low levels of wealth indicate a low level of enrolment into ECCE not only in Uzbekistan but also in Kazakhstan, Kyrgyzstan, and Tajikistan. The other variables are the age, gender of a child, number of children under five in the family, parent's marital status, and location of the pre-school settings: rural or urban areas, capital, or other regions. [14]

In 2017, the enrolment rate was still around 30\% in Uzbekistan. The investigations revealed that during the period of 1997-2014 there was no significant change in the percentage of pre-school enrolment. On the contrary, the number of pre-school settings decreased by $45 \%$. The reasons for that included the facts that ECCE entities did not possess satisfactory conditions; most of the teachers did not have enough qualification, they were employed with the secondary school certificates or vocational college diplomas; material-technical bases of the entities were not up to date; the curriculum was not well developed; the experience of developed countries in the related field was not well explored and implied. [15]

The turning point in the sphere of education, at all its levels, has been observed after the election of the President, Shavkat Mirziyoyev in 2016. Several reforms started being implemented in all spheres of life. These could be noticed from the adopted resolutions, decisions, decrees, and other normative documents. Specifically, the Decree of the President of the Republic of Uzbekistan No. PK-5198 of September 30, 2017 "On measures to improve the management of the preschool education system" states that the preschool education system is a critical link in the system of ongoing education. "Strengthening the technical base, providing them with qualified teaching staff, the introduction of modern educational programs and technologies that develop children in all respects intellectually, spiritually, aesthetically and physically in the educational process, raising their level of readiness for school". The same year, the Ministry of pre-school education was established in Uzbekistan. [16]

On May 8, 2019, the Presidential Decree approved the Concept for the Development of the Preschool Education System of the Republic of Uzbekistan until 2030 in order to further improve the system, ensure equal access to quality preschool education for children, and develop the nongovernmental sector of preschool education services [17].

According to the new system, pre-school educational institutions are established for the provision of educational, training, supervision, care and rehabilitation services for children between the ages 2-7 years in Uzbekistan. Additionally, the issue of qualification is being solved by retraining the leaders and teachers of educational settings in order to improve the quality of service. Moreover, the Institute of Retraining and Advanced Training of Managers and Specialists of Preschool Education Institutions was established. On May 8, 2019, the Presidential Decree approved the "Concept for the Development of the Preschool Education System of the Republic of Uzbekistan until 2030" in order to further improve the system, maintain equal access to quality preschool education for children, develop the non-governmental sector of preschool education services. Thus, the non-governmental sector is also developing and the number of private schools which were founded in partnership with the government reached over 6000 in the country [18].

Furthermore, statistics (UNICEF, 2020) show that Uzbekistan now has a 30\% expenditure on education and is making progress in the recognition of the importance of early childhood education. Enrolment in ECCE also grew rapidly from 30\% in 2017/2018 to 53\% in 2019/2020. It is planned to increase the rate to over $59 \%$ in the following year. However, the enrolment rate in the further regions is not satisfactory and children living there do not have equal access to ECCE. While the capital city Tashkent indicates the highest rate (87\%) of access for pre-schools, the southern part of the country show only around $30-39 \%$ access. Besides, children with disabilities attend separate specialized preschools, not inclusive mainstream schools. Another aspect to be improved is the low number of qualified teachers in pre-school settings. Unfortunately, only around $9 \%$ of pre-school educators were 
graduated from higher educational institutions. Moreover, the evaluation system of teachers requires improvements as well. Besides, the curriculum should be transformed and modernized too. It should be updated so that children not only memorize the content but learn how to think critically from a young age and apply acquired knowledge when and where needed. The upgrades in the system are arranged but it is necessary to make sure that the experience of developed countries is learned and applied if appropriate according to the values, traditions and culture of Uzbek society [19].

Overall, the analysis of the pre-school education system in Uzbekistan since the announcement of Independence in 1991 demonstrates significant positive changes in the field, particularly in the last few years. The recognition of the role of early childhood education was an essential step towards the improvement of the pre-school settings. On the other hand, due to the instability and lack of policies, monitoring in all levels of education for over 25 years, there are many reforms that have to be accomplished.

\section{CONCLUSIONS}

In this paper, the importance of early childhood education, lessons from developed countries, and the situational analysis of the pre-school education system as well as the ongoing reforms in Uzbekistan were discussed. It is important to highlight that provision of high-quality pre-school education will ensure improvements in economics too. While tackling the issues of early childhood education, the government may decrease the rate of unemployment, particularly among women. The cognitive development of children from the early ages will bring them such benefits as soft skills, which can be applied when they grow up and this will help to decrease social problems and even the number of criminals in the society [10]. At the same time, increasing the awareness of young mothers about the importance and role of early childhood education, persuading them to learn more and participate actively in the process of development of their children at home or as professionals in pre-school settings will maintain gender equality in the family and in the society.

\section{REFERENCES}

[1] The science of early childhood development. Center on the developing child, Harvard University, 2007. Available at: https://developingchild.harvard.edu/resources/inbrief-science-of-ecd/.

[2] Starting well. TalentEEducation. Economist, 2012. Available at: https://eiuperspectives.economist. com/talent-education/starting-well\#: :text=At $\% 20$ its $\% 20$ core $\% 2$ C $\% 20$ the $\% 20$ Starting,quality $\% 20$ of $\% 20$ such\%20preschool\%20environments.

[3] Burlacu F. The importance of pre-school education in child development. Euromentor Journal - Studies about education, 02 (2013), 153-165.

[4] Taiwo A.A., Tyolo J.B. The effect of pre-school education on academic performance in primary school: a case study of grade one pupils in Botswana. International Journal of Educational Development, 22 (2002), 169-180.

[5] Bibi W., Ali A. The Impact of Pre-school Education on the Academic Achievements of Primary School Students. The Dialogue, 7 (2) (2012), 152-185.

[6] Sparks S.D. Striking a Balance on Early Rigor. Education Week Spotlight on Critical Thinking, (2015), 2-4.

[7] Brophy J.E. Effective schooling for disadvantaged students. In: Knapp M.S., Shields P.M. (Eds.) Better schooling for the children of poverty. CA: Mccutchan Publishing, Berkeley, 2006.

[8] Bakken L., Brown N., Downing B. Early Childhood Education: The Long-Term Benefits. Journal of Research in Childhood Education, 31 (2) (2017), 255-269. doi: 10.1080/02568543.2016.1273285

[9] Sylva K. et al. The Effective Provision of Pre-school Education (EPPE) Project: Findings from pre-school to end of key stage 1. United Kingdom: Department for Education and Skills, Nottingham, 2004.

[10] Hanushek E.A., Woessman L. The role of cognitive skills in Economic Development. Journal of Economic Literature, 46 (3) (2008), 607-668. Available at: www.aeaweb.org/articles.php? doi: 10.1257/jel.46.3.607 
[11] Starting well. Benchmarking early education across the world. Economist Intelligence Unit, 2012.

[12] Habibov N. Early childhood care and education attendance in Central Asia. Children and Youth Services Review, 34 (4) (2012), 798-806.

[13] TransMonEE database. UNICEF, Geneva, 2013.

[14] Habibov N. On Individual, Household, and Community Factors Explaining Enrollment to Early Childhood Education and Care in Post-Soviet Transitional Countries. Springer Science+Business Media Dordrecht, 8 (2015), 825-843.

[15] Modern approach in the pre-school education system, 2017. Available at: http://www.uzlidep.uz /uz/pointview/39. (in Uzbek)

[16] Decree of the President of the Republic of Uzbekistan. No. PK-5198 of September 30, 2017. Available at: https://cis-legislation.com/document.fwx?rgn=101284.

[17] Decree of the President of the Republic of Uzbekistan. No. PK-4312 of May 08, 2019. Available at: https://lex.uz/docs/-4327235. (in Uzbek)

[18] Nabieva N. Changes in the preschool education system in Uzbekistan. International Journal on Orange Technologies, 02 (07) (2020), 17-19.

[19] Nordenmark A. et al. Situation Analysis of Children in Uzbekistan, 2019-2020. UNICEF.

Address: Nigora Mamadaminova, University of Adam Mickiewicz, 1 Wieniawskiego St., Poznań 61-712, Poland.

E-mail: nigmam@st.amu.edu.pl.

Received: 12.02.2021; revised: 29.03.2021.

Мамадамінова Нігора. Роль дошкільної освіти у розвитку дитини та аналіз існуючої системи дошкільної освіти в Узбекистані. Журнал Прикарпатського університету імені Василя Стефаника, 8 (1) (2021), 205-211.

У статті здійснено аналіз сучасної системи дошкільної освіти Узбекистану, представлено іiі основні виклики, недоліки та реформи. Автор вважає, що реалізоване дослідження наголошуе на важливості вивчення проблеми навчання у ранньому віці (3-5 років) та його впливу на майбутне навчання й особистий розвиток дітей. У дослідженні також подано аналіз вітчизняних і зарубіжних перспектив окресленої проблеми. Дослідниця вважає, що розвинені країни приділяють все більше уваги підвищенню якості роботи дошкільних навчальних закладів, ефективності навчальної програми та впровадженню більшої кількості соціальних заходів для посилення розвитку м'яких навичок дітей. Водночас у статті йдеться про те, що ситуація є зовсім іншою у таких країнах, що розвиваються, як наприкдад, Узбекистан. Таким чином, у статті наголошено на необхідності подальшого розгляду, реконструкції та модернізації системи дошкільної освіти та зокрема, ініціюванні деяких кампаній, спрямованих на розвиток особистісного та професійного розвитку молодої матері. Дослідження висвітлює вплив дошкільної освіти шляхом оцінки літератури в цій галузі, глибшого вивчення досвіду розвинених країн, а також розгдяду ситуації в Узбекистані щодо згаданої галузі. Висновки статті можуть бути використані для імплементації освітньої політики та сприяння розвитку всієї системи освіти Узбекистану.

Ключові слова: дошкільна освіта, дошкільна освіта, розвиток дитини, Узбекистан. 